\title{
READING NARRATIVE BY SEMANTIC MAPPING: A STRATEGY TO ENHANCE STUDENTS' COMPREHENSION
}

\author{
Durratul Hikmah \\ durrohhikmah@unuja.ac.id \\ Mohammad Sofyan Adi Pranata \\ sofyanadi@unuja.ac.id \\ Universitas Nurul Jadid Probolinggo
}

\begin{abstract}
This study attempted to investigate the effectiveness of using semantic mapping strategy for improving students' reading comprehension skill on narrative text. This study employed a quasi-experimental design by dividing the research group into control and experimental group. In this study, a pre-test and post-test experimental design with control group was used. The instruments used to collect the data were reading comprehension tests before and after the treatment. The study was conducted at grade VIII of SMP Nurul Jadid Probolinggo at which the students were identified as having problem in comprehending English narrative text. The finding showed that semantic mapping strategy can improve students' comprehension on reading narrative text.
\end{abstract}

Keywords: semantic mapping, reading comprehension, narrative text

\section{INTRODUCTION}

Based on the junior high school syllabus, English reading texts are including interpersonal, transactional, and functional discourse in the form descriptive, recount, narrative, procedure, report, explanation, analytical exposition, and news item at the level of informational literacy (Kemendikbud 2017). The expected competences of those reading texts are students are able to show an acceptable behavior in personal, social, academic, and profession environment; identify the social function, text structures, and linguistic features of short text; communicate interpersonally, transactional, and functionally; and capture the meaning and compose an oral and written text coherently with accurate and acceptable linguistic features. The learning competence of these texts, including narrative, is delivered through oral and written text. It can't be denied that the effectiveness of reading activity influences the quality of students' comprehension on narrative text. To support the process, a teacher should emphasize the reading activities to gain a deep understanding on the text. In another words, students are required to have good reading comprehension skills.

One of reading activities is reading comprehension. Reading comprehension is an activity carried out by the reader to connect new information with previous information to gain new knowledge (Sumadyo 2011, 9). Reading comprehension skills is a process of acquiring meaning, ideas, and information that actively involves the readers' knowledge and experience in writing discourse. Reading comprehension skill is based on 5 aspects as consisted in Barret's Taxonomy. First, literal comprehension, it emphasizes explicit information. Second, reorganization, it requires the reader to conduct an analysis, synthesis and organization of ideas or information that is implicit in the text. Third, inferential comprehension, it requires the reader to formulate a hypothesis or opinion based on information obtained from text. Fourth, evaluation, it is the 
reader's comprehension in assessing the quality, accuracy, and usefulness of information in reading. Fifth, appreciation, it emphasizes the readers' sensitivity on literary works emotionally and aesthetically (Gocer 2014, 4).

Reading comprehension on narrative text is different from other texts. In narrative text, the reading activities are directed at understanding the structure and building elements of story (Wibowo 2016). Narrative tells a story with a series of chronological and interconnected events that aim to entertain the reader (Astini 2017). Besides entertaining, narrative texts also imply life lessons in each of their stories.

This study chose the narrative text as a source of research because the narrative text as a literary text contains important values for students; they are personality values and academic values. Personality values carry students to get entertainment, inspiration, experience, empathy, noble heritage, moral values, and beauty. The academic value obtained from reading narrative texts is that students can develop their language skills, especially in reading and writing skill, and foster an appreciation of art. Therefore, by understanding the narrative text students learn to grow positive values on themselves.

Research on reading narrative texts has been widely conducted. Uchida, (2012) and Wibowo, Dawuh \& Priyatni, (2016) explained that teaching reading comprehension in narrative texts requires specific strategies to recognize students' cognitive styles. Uchida (2012) highlighted the use of repetition in the co-construction of stories and helps to clarify how the interlocutor constructs the same information in the narrative text. In addition, (Wibowo, Dawuh \& Priyatni 2016) focused on the use of PQ4R which was integrated with the concept mapping strategy to understand a short story based on students' cognitive styles. However, this strategy does not apply to students who cannot understand the meaning of the text. Besides, the two strategies have not guaranteed the readers to capture the moral message from the text.

Reading comprehension skill of narrative texts has an important role in learning activities. With good comprehension on narrative texts, it helps students in the learning process especially those related to Basic Competence. An understanding of these competencies will support students in learning the higher level of Basic Competence. Therefore, to get a maximum comprehension of narrative texts, the teacher needs to implement a certain learning strategy that is the semantic mapping.

Semantic mapping helps the students develop prior knowledge by seeing the relationship in a given topic. It is a visual representation of particular concept (Cooper et al. 2009: 102). This strategy is most effective when it is used before, during, and after reading and when the teachers serve as the guide or facilitator to their students who contrast own semantic maps. When semantic mapping is as pre-reading, it helps to active students' prior knowledge (schemata). Further, the teacher many use students' pre-reading semantic maps to determine how much knowledge building is required before students read the text (Antonnaci 2011, 18).

Using semantic reading in whilstreading help students to record the information obtained from the text. By making a semantic map during reading a text, the students' prior knowledge are complicated with the new information (Muhtar 2010, 61). When using semantic mapping as postreading, teachers can use students' discussions to help them organize information by connecting to words or concepts related to topic (Antonnaci et al. 2011, 18). However, a personal classroom illustration is probably the 
best way to gain an understanding of semantic mapping. The way to make students focused not just on the individual details but also on the construction of a text is Semantic mapping that might help in the conceptualization of paragraph and short essay structure.

Research on semantic mapping had been also conducted by many researchers, such as Zahedi \& Abdi (2012) and Wijayatiningsih \& Mulyadi (2012). They stated that semantic mapping is a useful strategy for reading a text in every level. This strategy can be implemented on every kind of texts. Besides, Supramaniam \& Zainal (2014) stated students enjoyed and learn better when semantic mapping strategy was implemented. Algazo (2015) investigated the use of SQ3R and semantic mapping learning among Jordanian University students, and it showed that these strategies were perfomed better. Furthermore, Kasim \& Wahyuni (2016) stated that the use of semantic mapping strategy was more effective that Grammar Translation method in improving students' reading comprehension. In expanding the previous research, it needs to conduct a research on the use of semantic mapping in understanding the narrative text.

Based on preliminary investigation, it was found that most students' reading comprehension of grade VIII SMP Nurul Jadid was relatively low. It was shown by the small number students who were able to understand the content of narrative text, determine the structure of the story, and the moral message of narrative text. There were several reasons behind it: (1) students felt bored with the material; (2) they found it as a text with difficult meaning; (3) they had difficulties in identifying the structure of the text and moral message in narrative text; and (4) the teacher had not used the appropriate learning strategy. Hence, these problems are the reason for conducting research on teaching reading comprehension of narrative texts at SMP Nurul Jadid.

Dealing with these conditions, it is necessary to think about and find the right solution to improve students' skills in reading comprehension. At present, many innovative learning strategies have been developed in the world of education. One strategy that can be used in improving reading comprehension is semantic mapping strategy.

Based on the statement above, the focus of this study is to look at the effectiveness of using semantic mapping to improve students' reading comprehension skills in narrative texts so as to facilitate students in determining the moral message in each type of narrative text. This strategy is expected to help students overcome their problems in understanding narrative texts. In addition, the implementation of semantic mapping in reading comprehension is expected to increase students' knowledge in reading English texts.

\section{RESEARCH METHOD}

Since this study examined the effectiveness of using semantic mapping strategy in improving students' reading comprehension, it used quantitative approach with quasi experimental design. It deals with Sugiyono's (2010, 72) statement that an experimental research is a used method to find the influence of certain treatment to other in a restrained condition. This study used quasi-experimental design because the study was in the natural setting but variables were isolated, controlled, and manipulated. The quasi-experiment design used was non-equivalent of pretest and post-test design (Creswell 2012 , 307). It meant that in this study, the task of experimental and control group was not randomly sampling. Both groups got pre-test and post-test and the experimental group was treated. The schema of the experimental model can be seen on Table 1 . 
In this study, the researchers used two variables. They are independent variable and dependent variable. The independent variable is semantic mapping and the dependent variable is students' reading comprehension. In other words, semantic mapping as independent variable influences the students' reading comprehension as dependent variable.
After getting pre-test, both groups were given different teaching-learning process as the treatment. The experimental group got teachinglearning process with semantic mapping strategy. On the contrary, the control group got teaching-learning process without semantic mapping. The teaching learning process was held in four meetings in each group. The first

Table 1: The Schema of the Quasi-experimental Design

\begin{tabular}{lccc}
\hline \multicolumn{1}{c}{ Group } & Pre-test & Treatment & Post-test \\
\hline Experimental & $\mathrm{O}_{1}$ & $\mathrm{X}$ & $\mathrm{O}_{2}$ \\
Control & $\mathrm{O}_{3}$ & - & $\mathrm{O}_{4}$ \\
\hline
\end{tabular}

Note:

$\mathrm{O}_{1}$ : Pre-test of experimental group

$\mathrm{O}_{2}$ : Post-test of experimental group

$\mathrm{O}_{3}$ : Pre-test of control group

$\mathrm{O}_{4}$ : Post-test of control group

$\mathrm{X}$ : Treatment

\section{- $\quad$ : No treatment}

The population of this study was all students in eighth grade of SMP Nurul Jadid, Probolinggo which consist of seven classes. The sampling technique of this study used cluster sampling. Cohen $(2007,112)$ stated when the population is large and widely dispersed, the researcher can select a specific number of groups within the population, and it is called cluster sampling. Afterwards, the researchers took two classes as the sample of this study. They are class VIII-H as the experimental group and class VIII-I as the control group. The study was conducted from June-July 2019.

To know the students' test result, the pre-test was given to both groups and held before the treatment. The function is to know the students' basic ability in reading achievement. Before taking the pre-test, students were not taught any material deals with narrative text as the basic knowledge. There were 25 students of class VIII-H as the experimental group and 26 students of VIII-I as the control group joined the test. and second meeting was measured by test 1 , while the third and fourth meeting was measured by test 2 . The post-test was also given to both groups and held after treatment to decide the effectiveness of semantic mapping. The process was similar to pre-test. The students got 20 multiple choices questions with 4 reading texts.

In collecting data, the researcher used test. The test used to obtain the data of students' reading comprehension. The tests used for pretest and post-test were adopted from English in Focus for Grade VIII Junior High School and Detik-detik Ujian Nasional Bahasa Inggris. The test was a multiple choice reading test consisting 20 questions with four reading texts. It had to be done in 90 minutes. After the students finished the test, the score was calculated. Since it was multiple choices, the score of each question was 5 point. The types of questions are arranged based on the cognitive aspects of Bloom Taxonomy in Anderson (2001), which are simple questions (knowledge, 
comprehension) and high-level questions (applications).

For the instrument technique analysis, the researchers needed validity and reliability. The validity first test, the third meeting and the fourth meeting was measured by the second test and the last test was given a post-test to measure the overall ability from the first to the fourth meeting.

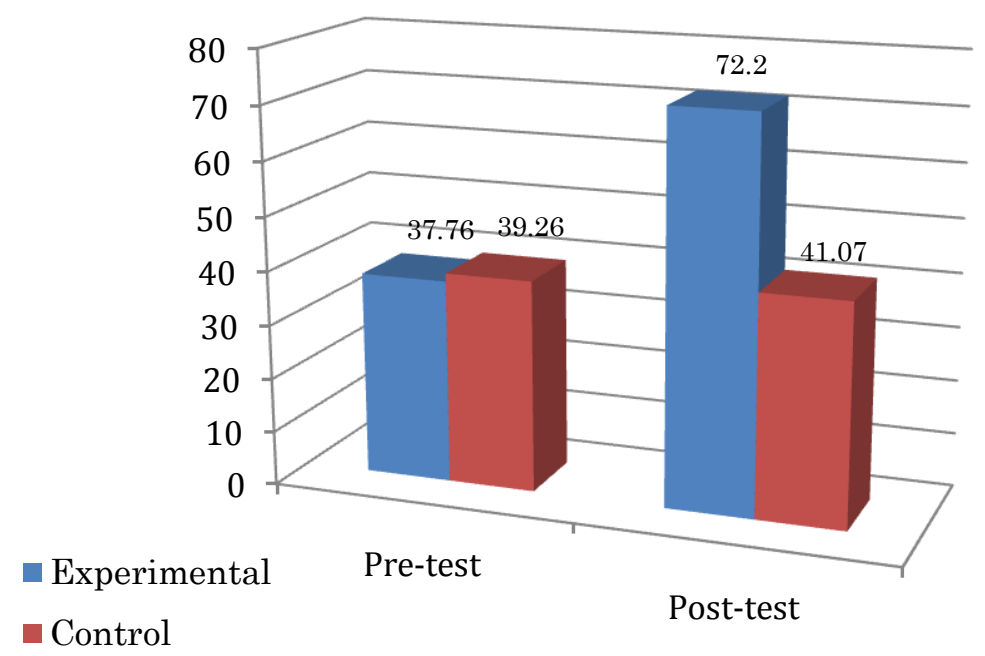

Figure 1: Students' pre-test and post-test score result

used was content validity by involving two lectures of English Education program and one English teacher from SMP Nurul Jadid. Based on interrater's result, the test obtained a high reliability coefficient of 0.992 which means the measurement of students' score was highly consistent.

In analyzing the data, the researchers used test for equality of variance, normality test, and homogeneity test. The test for equality of variance was used to prove that the samples had the homogeny ability. Afterwards, normality test was used by using Kolmogorov-Smirnov and Shapiro-Wilk test through SPSS 16 for windows. The data was then analyzed by homogeneity test using Levene's test to know the variance homogeny. Furthermore, independent sample t-test was used to test the hypothesis.

\section{RESUlTS AND Discussions}

The learning process was carried out in four meetings. The increasing of the experimental class's reading comprehension ability was in the first and second meetings measured by the
Conversely, the increase of the control class's reading comprehension was only measured by pre-test and post-test. The pre-test mean score of students' reading comprehension in the experimental class was 37.76 while the pre-test mean score of the control class students was 39.26. It showed that the mean pretest score of the experimental class was lower than the control class. However, the difference of scores of the both classes was not too visible. In homogeneity, the ability of students in the two groups was alike. The comparison of the pre-test and post-test mean scores of students' reading comprehension in the experimental and control class is shown in Figure 1.

Figure 1 showed that the pre-test mean score of the experimental class was lower than the control class $\left(\overline{\mathrm{X}}_{\text {experimental }}=37.76<\overline{\mathrm{x}}_{\text {control }}=39.26\right)$. It meant that the ability of students' reading comprehension in control class before being applied the semantic mapping strategy was better than the experimental class although it was not too large; the range was around 1.5 points. However, there was a better 
increasing score after implementing the semantic mapping strategy; it was the post-test mean score of the experimental class was 31.15 points greater than the control class $\left(\overline{\mathrm{x}}_{\text {experimental }}=72.20>\overline{\mathrm{x}}_{\text {control }}=41.07\right)$.
The normality test in this study used the Kolmogorov Smirnov and Shapiro-Wilk tests. The results of the normality test of data on the reading comprehension of the experimental class and control class used SPSS 16.0

Table 2: Test of Normality

\begin{tabular}{lrrrrrr}
\hline & \multicolumn{3}{c}{ Kolmogorov-Smirnov $^{\mathrm{a}}$} & \multicolumn{3}{c}{ Shapiro-Wilk } \\
Group & Statistic & Df & Sig. & Statistic & Df & Sig. \\
\hline Experimental & .141 & 25 & $.200^{*}$ & .924 & 25 & .063 \\
Control & .161 & 25 & .094 & .949 & 25 & .237 \\
\hline
\end{tabular}

Based on the research above, the mean score of the pretest and post-test was different. The post-test mean score of the control class was lower than the experimental class which was $41.07<$ 72.20. However, the researchers had not been able to state that the semantic mapping in the experimental class was more effective than the use of conventional methods in the control class because both classes had different pre-test mean scores. Hence, the researchers used paired sample t-test analysis to compare the mean values of the two classes that received different treatments. Paired sample t-test is part of parametric statistical analysis. for Windows are shown in Table 2.

Table 2 described the normality test result of students' reading comprehension. The testing criteria is if sig $\geq 0.05$, it means the $\mathrm{H}_{0}$ was accepted (data is normally distributed); if sig $\leq$ 0.05 , it means the $\mathrm{H}_{1}$ is rejected (data is not normally distributed). In Kolmogorov-Smirnov table for experimental class, the score of sig was 0.200 . Since sig in this table is $\geq 0.05$ $(0.200 \geq 0.05)$, it meant the $\mathrm{H}_{0}$ was accepted (the data was normally distributed). Besides, in Shapiro-Wilk table for experimental class, the score of sig was 0.063 . Since sig was $\geq 0.05$ $(0.063 \geq 0.05)$, it meant $\mathrm{H}_{0}$ was accepted

Table 3: Levene's Test for Homogeneity Test

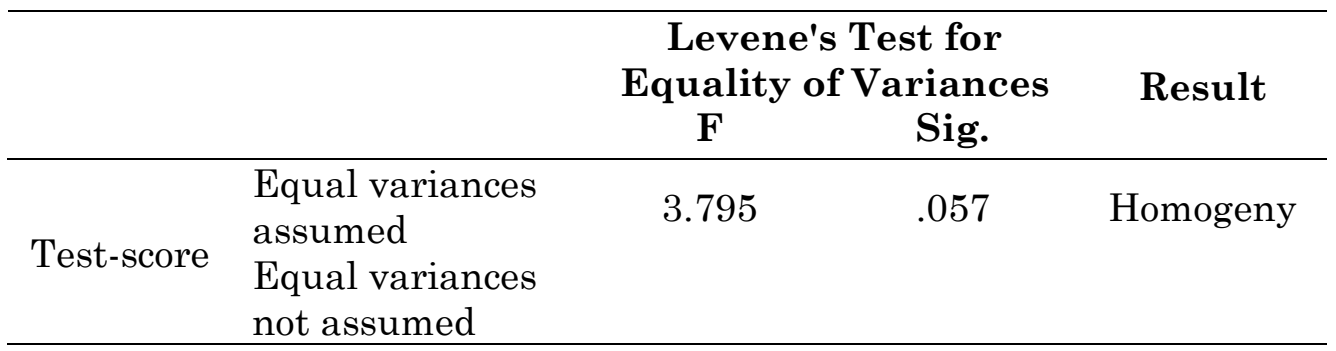

Therefore, as a basic rule in parametric statistical analysis, the main requirement is that research data must be normally distributed. To find out whether the data that is used in paired sample t-test testing is normally distributed or not, the researcher needed to do a normality test and homogeneity test in both experimental classes and the control class. (the data is normally distributed). Furthermore, the score of control group sig in Kolmogorov-Smirnov table was 0.094 . Since the sig score was $\geq 0.05$ $(0.094 \geq 0.05)$, it meant that $\mathrm{H}_{0}$ was accepted (data was normally distributed). In Shapiro Wilk table for control class, the score of sig was 0.237. Since the sig score was $\geq 0.05(0.237 \geq$ $0.05)$, it meant that $\mathrm{H}_{0}$ was accepted (data was normally distributed). After 
conducting normality test, it continued to conducting homogeneity test for individual reading comprehension of experimental class and control class by using Laavene's test. The result of homogeneity test for experimental class and control class was shown in Table 3.

Table 3 indicated the F-test score was 3.795 , and the score of sig was 0.057 . Since sig was $0.057 \geq 0.05$, it meant the $\mathrm{H}_{0}$ was accepted (the variant in each group is similar or homogeneous). Thus, it could be concluded that the score of students' reading comprehension by using a semantic mapping (experimental class) and without semantic mapping (control class) was homogeneous or similar. increase score of pre-test to post-test in experimental group. The students' score in experimental group increased 34\% from pre-test to post-test, while the control group students' score increased $2 \%$ from pre-test to post test. Besides, Based on the output of independent samples T-test by using SPSS, the pvalue was 0.00 , in this research the significant level was $0.05(p=0.05)$. So the result of the class $p$-value was lower than 0.05 , meaning that $\mathrm{H}_{0}$ was rejected. It means that the alternative hypothesis $\left(\mathrm{H}_{1}\right)$, which was "The students are taught using semantic mapping have better reading comprehension than those who are taught without semantic mapping", was

Table 4: T-test Result of Experimental and Control Class

\begin{tabular}{ccc}
\hline p-value & Significant level & Result \\
\hline 0.000 & 0.05 & $\mathrm{H}_{0}$ was rejected/H $\mathrm{H}_{1}$ was accepted \\
\hline
\end{tabular}

Since the normality and homogeneity test showed that the data spreads normally and the two variances were homogeneous, so the hypothesis test used was t-test with two homogeneous variances. The results of t-test with two homogeneous variants using the SPSS 16.0 for Windows program are shown in Table 4.

Table 4 stated the p-value is lower than significant level score $(p<0.05)$. Consequently, the null hypothesis $\left(\mathrm{H}_{0}\right)$ was rejected and alternative hypothesis $\left(\mathrm{H}_{1}\right)$ was accepted. Thus, based on statistical calculations it is proven that there is a significant difference between reading test scores in the experimental class and the control class. In other words, the application of semantic mapping strategies can significantly improve students' reading comprehension skills in narrative texts.

\section{ConClusion}

Based on the result analysis, it indicated that semantic mapping strategy is effective strategy in enhancing students' reading comprehension. It was shown by the accepted. This result means that teaching reading comprehension with semantic mapping is more effective than teaching with conventional method.

\section{REFERENCES}

Al-Ghazo, Abeer. 2015. "The Effect of SQ3R and Semantic Mapping Strategies on Reading Comprehension Learning among Jordanian University Students". International Journal of English and Education, 4 (3): 92-106. <http://ijee.org/ yahoo_site_admin/assets/docs/9.1901063 1.pdf $>$

Anderson, LW \& David R. Krathwohl. 2001. A Taxonomi for Learning, Teaching, and Assesing: A Revision of Bloom's of Educational Objectives. Boston: Allyn \& Bacon

Antonacci, P \& CM O'Callaghan. 2011. Developing Content Area Literacy. London: SAGE Publication Ltd.

Astini, Risti. 2017. "Narrative". $<$ https://www.englishcafe.co.id/ pengerti an-narrative-text-dalam-bahasa-inggris -beserta-contohnya/

Cooper, et al. 2009. Literacy: Helping Student Construct Meaning. Boston: Cengage Learning, Inc. 
Cohen, Manion \& Keith Morrison. 2007. Research Method in Education (6 (th $^{\text {th }}$ ed): New York: Routledge

Creswell, John W. 2012. Planning, Conducting, and Evaluating Quantitative and Qualitative Research $\left(4^{\text {th }}\right.$ ed). New York: Pearson Education, Inc.

Gocer, Ali. 2014. "The Assessment of Turkish Written Examination Questions Based on the Text in Accordance with the Barrett's Taxonomy". International Journal of Languages' Education and Teaching 3: 1-16. <https://eric.ed.gov/?id=ED557158 $>$

Kemdikbud. 2017. Model Silabus Mata Pelajaran Sekolah Menengah Pertama/Madrasah Tsanawiyah (SMP/MTs); Mata Pelajaran Bahasa Inggris. Jakarta: Kementerian Pendidikan dan Kebudayaan

Kasim, Usman, \& Sri Wahyuni. 2016. "Implementation of the Semantic Mapping Strategy for Teaching Reading Comprehension". English Education Journal, 7 (1): 46-60. <http://jurnal. unsyiah.ac.id/index.php/EEJ/article/vie w/3160>

Muhtar, Kamal. 2010. Improving Students' Reading Comprehension Through Semantic Mapping Strategy: An Action Research in the Eighth Year Students of SMPN 1 Sine in the 2009/2010 Academic Year (Master Thesis). Surakarta: Universitas Sebelas Maret

Sumadyo, Samsu. 2011. Strategi dan Teknik Pembelajaran Membaca. Yogyakarta: Graha Ilmu
Sugiyono. 2010. Metode Penelitian Pendidikan Pendekatan Kuantitatif, Kualitatif, dan R\&D. Bandung: Alfabeta

Supramaniam, Elamathi, \& Zainal, Zaidah. 2014. "The Effects of Semantic Mapping on Reading Comprehension". LSP International Journal, 1: 61-74 $<$ https://lspinternationaljournal.utm.my /index.php/lspij/article/download/12/8>

Uchida, Lala. 2012. "Allo-repetition in English Narratives: Functional Distribution and Collaboration between Storytellers and Story-recipients", Research Gate Conference Paper $<$ https://www.researchgate.net/publicati on/308950965>

Wibowo, Prasetyo Adi, Dawud, \& Endah Tri Priyatni. 2016. "Penggunaan Strategi PQR4 Berbantuan Peta Konsep dalam Membaca Pemahaman Teks Cerita Pendek Sesuai Gaya Kognitif Siswa", Jurnal Pendidikan: Teori, Penelitian, dan Pengembangan, 1 (12); 2395-2406

Wijayantiningsih, Testiana Deni, \& Dodi Mulyadi. 2012. "Penerapan Strategi Semantic Mapping untuk Meningkatkan Keterampilan Menulis Teks Report Bagi Mahasiswa Ilmu Keperawatan Unimus", Seminar Hasilhasil Penelitian-LPPM Unimus. Semarang: Unimus

Zahedi, Yagoub, \& Mortaza Abdi. 2012. "The Effect of Semantic Mapping on EFL Learner's Vocabulary Learning". Procedia Social and Behavioral Sciences 69: 2273-2280 